\title{
Delta cell secretory responses to insulin secretagogues are not mediated indirectly by insulin
}

\author{
A. C. Hauge-Evans • R. L. Anderson - S. J. Persaud • \\ P. M. Jones
}

Received: 16 January 2012 / Accepted: 9 March 2012 / Published online: 13 April 2012

(C) Springer-Verlag 2012

\begin{abstract}
Aims/hypothesis Somatostatin from islet delta cells inhibits insulin and glucagon secretion, but knowledge of the regulation of pancreatic somatostatin release is limited. Some insulin secretagogues stimulate somatostatin secretion, and here we investigated whether delta cell secretory responses are indirectly regulated in a paracrine manner by insulin released from beta cells.

Methods Hormone release from static incubations of primary mouse islets or somatostatin-secreting TGP52 cells was measured by RIA. mRNA expression was assessed by RT-PCR. Results Glucose and a range of other physiological and pharmacological agents stimulated insulin and somatostatin release, and insulin receptor mRNA was expressed in islets, MIN6 beta cells and TGP52 cells. However, exogenous insulin did not modulate basal or glucose-induced somatostatin secretion from islets, nor did pre-incubation with an antibody against the insulin receptor or with the insulin receptor tyrosine kinase inhibitor, $\operatorname{HNMPA}(\mathrm{AM})_{3}$. Glucose and tolbutamide stimulated somatostatin release from TGP52 cells, whereas a range of receptor-operating agents had no effect, the latter being consistent with a lack of corresponding receptor mRNA expression in these cells. Parasympathetic activation stimulated insulin, but inhibited
\end{abstract}

Electronic supplementary material The online version of this article (doi:10.1007/s00125-012-2546-9) contains peer-reviewed but unedited supplementary material, which is available to authorised users.

A. C. Hauge-Evans $(\bowtie) \cdot$ R. L. Anderson · S. J. Persaud •

P. M. Jones

Diabetes Research Group, Division of Diabetes and Nutritional

Sciences, School of Medicine, King's College London,

Guy's Campus, London Bridge,

London SE1 1UL, UK

e-mail: astrid.hauge_evans@kcl.ac.uk somatostatin release from mouse islets in accordance with differences in muscarinic receptor mRNA expression in islets, MIN6 and TGP52 cells. The inhibitory effect on somatostatin secretion was reversed by pertussis toxin or the muscarinic receptor 2 antagonist, methoctramine.

Conclusions/interpretations A number of insulin secretagogues have analogous effects on insulin and somatostatin release, but this similarity of response is not mediated by an indirect, paracrine action of insulin on delta cells.

Keywords Delta cell · Insulin · Intra-islet communication . Islets · Muscarinic M2 receptors · Paracrine .

Somatostatin - TGP52

$\begin{array}{ll}\text { Abbreviations } \\ \text { GLP-1 } & \text { Glucagon-like peptide 1 } \\ \text { GLP-1R } & \text { GLP-1 receptor } \\ \text { IR-AB } & \text { Insulin receptor antibody } \\ \text { M2 } & \text { Muscarinic receptor 2 } \\ \text { M3 } & \text { Muscarinic receptor 3 } \\ \text { M4 } & \text { Muscarinic receptor 4 } \\ \text { MTT } & \text { Methoctramine tetrahydrochloride } \\ \text { PI3-K } & \text { Phosphoinositide 3-kinase } \\ \text { PMA } & \text { Phorbol myristate acetate } \\ \text { PTX } & \text { Pertussis toxin }\end{array}$

\section{Introduction}

Insulin-secreting beta cells are located in the islets of Langerhans, which have a complex three-dimensional structure that also contains other cell types, the most numerous of which are glucagon-secreting alpha cells and somatostatinsecreting delta cells. Previous work has demonstrated that interactions between cells within the islet are essential for 
ensuring the appropriate pattern of insulin secretion [1-5]; and possible interactions between alpha and beta cells within islets have been well studied [1, 6-9]. For example, alpha cells express the insulin receptor [7] and a number of studies suggest that beta cells negatively regulate glucagon secretion, although it is uncertain whether the paracrine agent is insulin, zinc co-released with insulin or some other beta cell secretory product [7-10]. Less attention has been paid to the potential intra-islet roles of delta cell-derived somatostatin, but from studies of somatostatin-deficient mice, we recently identified an important paracrine role in the regulation of islet hormone secretion, where locally released delta cell somatostatin inhibited insulin and glucagon secretion [11].

To understand the roles of delta cell somatostatin in the regulation of islet function, it is essential to know how physiologically relevant stimuli affect somatostatin release from islet delta cells. Current knowledge of the regulation of somatostatin secretion is limited, but the available evidence suggests that delta cells respond similarly to beta cells. Accordingly, some studies have demonstrated that glucose stimulates both insulin and somatostatin release [11, 12], as do membrane-depolarising agents such as arginine and sulfonylureas [11,13-16], as well as the incretin, glucagon-like peptide 1 (GLP-1) [15-20]. These observations may reflect similar stimulus-response coupling mechanisms in beta and delta cells, but they could also suggest that delta cell secretory responses are indirectly regulated in a paracrine manner by insulin released from beta cells. Single-cell PCR measurements have shown that some islet delta cells express INSR mRNA [21], but the role of insulin in the regulation of somatostatin release is unclear. No or little effect of insulin has been reported on somatostatin secretion from isolated rat islets [22] or perfused canine pancreas [23, 24], although stimulatory effects were seen in perfused human pancreas [25]. Interestingly, Trimble et al [26] found that rat islets from a streptozotocin-induced model of diabetes were glucose-insensitive with regard to somatostatin release, but that responsiveness was restored upon in vivo treatment with insulin, consistent with glucose-induced somatostatin release being secondary to insulin release.

In the present study, we used exogenous insulin and insulin receptor antagonists to investigate a potential paracrine role of endogenous insulin in the regulation of somatostatin secretion. We also assessed the secretory capacity of a somatostatin-secreting cell line, TGP52, to investigate whether the secretory characteristics of somatostatin are maintained in the absence of any beta cell input.

\section{Methods}

Ethics Experiments involving animals were approved by the local ethics committee.
Islet isolation Islets from male ICR mice ( $30 \mathrm{~g}$; Charles River, Margate, UK) were isolated by collagenase digestion $(1 \mathrm{mg} / \mathrm{ml}$, type XI; Sigma, Poole, UK) and separated from exocrine pancreatic tissue on a histopaque gradient (Sigma), as described previously [11]. Islets were incubated overnight at $37^{\circ} \mathrm{C}$ $\left(5 \% \mathrm{CO}_{2}\right)$ in RPMI 1640 medium ( $10 \%$ [vol./vol.] FBS, $2 \%$ [vol./vol.] glutamine, $100 \mathrm{U} / \mathrm{ml}$ penicillin with $0.1 \mathrm{mg} / \mathrm{ml}$ streptomycin, $11 \mathrm{mmol} / 1$ glucose) prior to experiments.

Tissue culture Somatostatin-secreting TGP52 cells (passages 21-28; ATCC, Manassas, VA, USA) and MIN6 cells (passage 32) were maintained at $37^{\circ} \mathrm{C}$ and $5 \% \mathrm{CO}_{2}$ in $1: 1$ DMEM Ham's F12 (10\% [vol./vol.] FBS, 0.5 mmol/1 sodium pyruvate, $100 \mathrm{U} / \mathrm{ml}$ penicillin with $0.1 \mathrm{mg} / \mathrm{ml}$ streptomycin, $17.5 \mathrm{mmol} / \mathrm{l}$ glucose) and DMEM (10\% [vol./vol.] FBS, $2 \mathrm{mmol} / 1$ glutamine, $100 \mathrm{U} / \mathrm{ml}$ penicillin with $0.1 \mathrm{mg} / \mathrm{ml}$ streptomycin, $25 \mathrm{mmol} / \mathrm{l}$ glucose), respectively. The medium was changed every 3 days, and the cells were passaged and used for experiments when $70 \%$ to $80 \%$ confluent.

Hormone secretion studies Hormone release was assessed in static incubation experiments. Islets were pre-incubated for $60 \mathrm{~min}$ at $37^{\circ} \mathrm{C}$ in a bicarbonate-buffered physiological salt solution [27] containing $1 \mathrm{mmol} / 1$ glucose, after which batches of 12 islets were incubated for $60 \mathrm{~min}$ in $0.4 \mathrm{ml}$ salt solution with the agents of interest. TGP52 cells were seeded at a density of 200,000 cells/well in 12-well plates and cultured for $24 \mathrm{~h}$ to allow for cell attachment. The cells were then pre-incubated and incubated as above in $0.5 \mathrm{ml}$ salt solution. The pharmacological agents, phorbol myristate acetate (PMA) and forskolin, were routinely included with other secretagogues as internal controls for secretory responsiveness. For assessment of hormone content, islets or trypsinised cells were washed twice with PBS, pelleted by centrifugation $(200 \times g)$, lysed in acidified ethanol and sonicated. Exogenous insulin from bovine pancreas (containing approximately $0.5 \%$ zinc) was obtained from Sigma UK. A rabbit antibody specific to the insulin-binding region (aa702-719) of the alpha subunit of the insulin receptor (type A and B) was from Biogenesis (Poole, UK) and the insulin receptor tyrosine kinase inhibitor, $\operatorname{HNMPA}(\mathrm{AM})_{3}$, was from Calbiochem (La Jolla, CA, USA). The phosphoinositide 3-kinase (PI3-K) inhibitor, LY294002, and methoctramine tetrahydrochloride (MTT) were obtained from Cambridge Bioscience (Cambridge, UK) and MP Biomedicals (Cambridge, UK), respectively.

The hormone content of cell lysates and incubation media was assessed by RIA, using an in-house insulin or glucagon assay as described previously [11] and a commercially available somatostatin RIA kit (Euro-Diagnostica, Malmö, Sweden).

For the assessment of protein content, islets or trypsinised cells were washed twice with PBS, pelleted by centrifugation 
$(200 \times g)$, lysed in $0.5 \mathrm{~mol} / 1 \mathrm{NaOH}$ and sonicated. Protein content was measured using Bradford's protein assay [28].

$R T-P C R$ RNA was extracted from islets and cells using a kit (RNAeasy; Qiagen, Crawley, UK). Reverse transcription to cDNA and PCR amplification were performed as described previously [29] using the cycle variables and primer sequences listed in electronic supplementary material Table 1 . The primer sets for the insulin receptor were designed to detect mRNA of isoforms A and B. Products were separated on agarose gels and visualised by staining with ethidium bromide $(0.1 \mu \mathrm{g} / \mathrm{ml})$.

Data analysis Data are expressed as means \pm SEM, and analysed using one-way ANOVA and Bonferroni's multiple comparisons test. Differences between treatments were considered significant at $p<0.05$.

\section{Results}

Regulation of somatostatin release by modulators of insulin secretion Glucose and two other initiators of insulin secretion, tolbutamide and arginine, stimulated the release of insulin and somatostatin from primary mouse islets (Fig. 1a-c). The effect of glucose was concentration-dependent, resulting in a significant release of both hormones at $20 \mathrm{mmol} / \mathrm{l}$, with no significant changes observed at $5 \mathrm{mmol} / \mathrm{l}$ glucose. The mean results from six separate experiments (Fig. 1a, b) demonstrate that insulin and somatostatin release was enhanced at 7 and $10 \mathrm{mmol} / 1$ glucose. However, analysis of individual experiments showed that statistically significant effects on somatostatin and insulin secretion were only obtained in three of six individual experiments at $10 \mathrm{mmol} / \mathrm{l}$ glucose, reflecting the variability of responses between different islet preparations at these intermediate glucose concentrations.

Glucagon (Fig. 1d) and the GLP-1 analogue, exendin-4 (Fig. 1e), also potentiated glucose-induced insulin and somatostatin secretion from mouse islets. In contrast, exendin-4 had no effect on basal $(1 \mathrm{mmol} / \mathrm{l}$ glucose $1.74 \pm 0.25 \mathrm{fmol}$ islet $^{-1} \mathrm{~h}^{-1}[$ means $\pm \mathrm{SEM}] ; 1 \mathrm{mmol} / 1$ glucose $+10 \mathrm{nmol} / 1$ exendin-4 $2.09 \pm 0.14 ; p>0.2$ ) or arginineinduced $\left(20 \mathrm{mmol} / 1\right.$ arginine $3.23 \pm 0.39 \mathrm{fmol}_{\text {islet }}{ }^{-1} \mathrm{~h}^{-1}$; $20 \mathrm{mmol} / \mathrm{l}$ arginine $+10 \mathrm{nmol} / \mathrm{l}$ exendin-4 $3.16 \pm 0.51 ; p>0.2$ ) somatostatin release, as previously reported for insulin [30]. The sympathetic neurotransmitter, noradrenaline (norepinephrine), reduced glucose-induced hormone secretion to basal levels or below (Fig. 1f), whereas pharmacological activation of adenylyl cyclase by forskolin or protein kinase $\mathrm{C}$ by PMA strongly potentiated glucose-induced insulin and somatostatin release, although effects on the latter were less pronounced (Fig. 1g, h).
Effect of insulin on somatostatin release Insulin receptor mRNA was expressed in the somatostatin-secreting TGP52 cell line, the MIN6 beta cell line and in mouse islets (Fig. 2a), supporting a previous report by our team on insulin receptor expression in single islet beta and delta cells [21]. To assess whether the observed similarity in secretory responses of delta and beta cells was due to an indirect effect of insulin action on delta cell insulin receptors, somatostatin release from mouse islets was measured in the presence of exogenous insulin $(100 \mathrm{nmol} / \mathrm{l})$. No insulin-induced changes in somatostatin secretion were observed at low, intermediate or high glucose concentrations (Fig. 2b), although insulin did inhibit noradrenaline-induced glucagon secretion $(10 \mu \mathrm{mol} / 1$ noradrenaline $+100 \mu \mathrm{mol} / 1$ ascorbic acid $46.6 \pm$ $10.6 \mathrm{ng}$ glucagon islet ${ }^{-1} \mathrm{~h}^{-1}$ [means \pm SEM]; $10 \mu \mathrm{mol} / 1$ noradrenaline $+100 \mu \mathrm{mol} / 1$ ascorbic acid $+100 \mathrm{nmol} / 1$ insulin $22.0 \pm 4.0 ; n=7, p<0.05)$. Similarly, pharmacological blockade of insulin receptor signalling using an insulin receptor antibody (IR-AB) $(1 \mu \mathrm{g} / \mathrm{ml}, 48 \mathrm{~h})$ or the insulin receptor tyrosine kinase inhibitor, $\operatorname{HNMPA}(\mathrm{AM})_{3}(10 \mu \mathrm{mol} / 1,1 \mathrm{~h})$, did not reduce the secretory response of islet delta cells to increasing glucose concentrations (Fig. 2c, d). Activation of the insulin receptor is known to trigger PI3-K-mediated signalling pathways, but the PI3-K inhibitor, LY294002, did not reduce glucose-induced somatostatin release. In contrast, the compound did stimulate glucose-induced somatostatin release $(20 \mathrm{mmol} / 1$ glucose $1.85 \pm 0.19 \mathrm{fmol}$ islet $^{-1} \mathrm{~h}^{-1} ; 20 \mathrm{mmol} / 1$ glucose $+10 \mu \mathrm{mol} / 1 \mathrm{LY} 2940023.21 \pm$ $0.3 ; p<0.001)$ and insulin secretion $(20 \mathrm{mmol} / \mathrm{l}$ glucose $1.63 \pm$ $0.11 \mathrm{ng}$ islet $^{-1} \mathrm{~h}^{-1} ; 20 \mathrm{mmol} / 1$ glucose $+10 \mu \mathrm{mol} / 1 \mathrm{LY} 294002$ $5.22 \pm 0.58 ; p<0.001)$. The IR-AB was used under conditions that have previously been shown to inhibit insulin action [31, 32]; similarly, $10 \mu \mathrm{mol} / 1 \mathrm{HNMPA}(\mathrm{AM})_{3}$ and $10 \mu \mathrm{mol} / \mathrm{l} \mathrm{LY}$ 294002 were found to reverse the effect of insulin on noradrenaline-induced glucagon release in parallel secretion experiments.

Secretory characteristics of the somatostatin-secreting TGP52 cell line To investigate whether delta cell somatostatin secretory responses were maintained in the absence of any influence from beta cells, the secretory characteristics of TGP52 cells were determined. The cells produced somatostatin, but at very low levels compared with those of primary islets (TGP52 $0.42 \pm 0.14 \mathrm{fmol} / \mu \mathrm{g}$ protein $[$ means $\pm \mathrm{SEM}$ ]; mouse islets $112.2 \pm 25 ; p<0.01$ ). Their secretory responsiveness was variable, with glucose-induced somatostatin release only observed in four of six experiments $(p>0.2)$ (Fig. 3a). Tolbutamide exerted a small stimulatory effect on somatostatin secretion $(p=0.06)$, and somatostatin release was increased in response to forskolin or PMA (Fig. 3a). There was no concomitant detection of insulin ( $p>0.2$ vs $0 \mathrm{ng}$ insulin/ml standard in RIA), demonstrating that TGP52 cells did not secrete measurable amounts of insulin, nor was 
Fig. 1 Effect of nutrients and receptor-operating and pharmacological agents on insulin and somatostatin release from primary mouse islets. a Insulin and (b) somatostatin (SST) secretion in response to increasing concentrations of glucose. c Insulin (white bars) and somatostatin (black bars) secretion in response to tolbutamide and arginine, (d) glucagon, (e) the GLP-1 analogue, exendin-4 (Ex-4), and (f) the neurotransmitter noradrenaline (NA, with $100 \mu \mathrm{mol} / \mathrm{l}$ ascorbic acid).

g The secretory responses to the pharmacological agents forskolin (FSK, with $100 \mu \mathrm{mol} / 1$ isobutylmethylxanthine) and (h) PMA. Data $(\mathbf{a}, \mathbf{b})$ are presented as means \pm SEM of five to six experiments; data $(\mathbf{c}-\mathbf{f})$ are expressed in percentage of basal secretion as means + SEM from individual experiments, each representative of three to five separate experiments with six to ten observations per treatment group. ${ }^{*} p<0.05$, $* * p<0.01$ and $* * * p<0.001$, respectively, vs $1 \mathrm{mmol} / 1 \mathrm{glu}-$ cose alone; ${ }^{\dagger} p<0.05,{ }^{\dagger \dagger} p<0.01$ and ${ }^{\dagger \dagger} p<0.001$, respectively, vs 10 or $20 \mathrm{mmol} / 1$ glucose alone; $p$ values by one-way ANOVA and Bonferroni's multiple comparisons test a

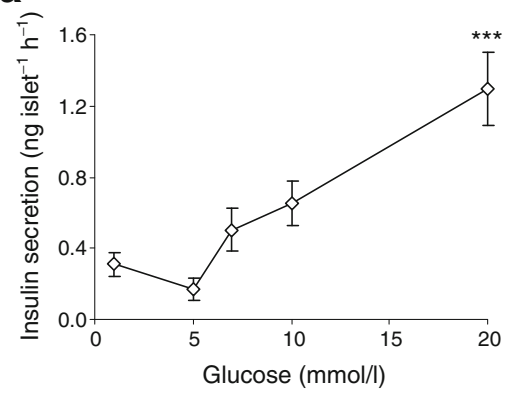

C

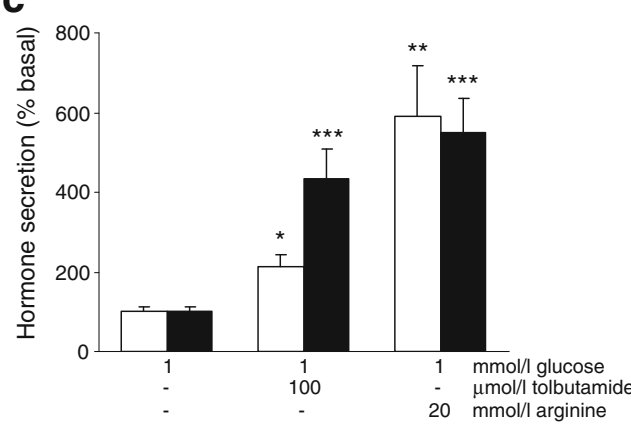

e

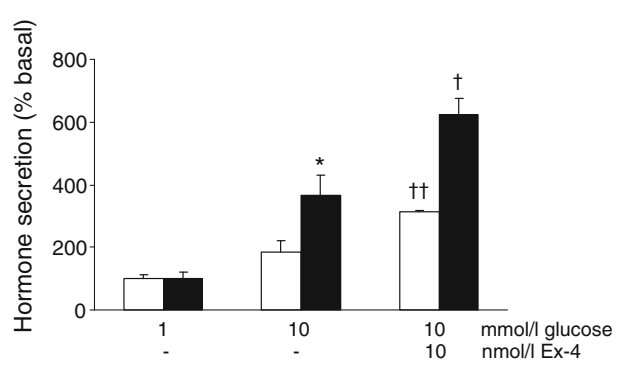

g

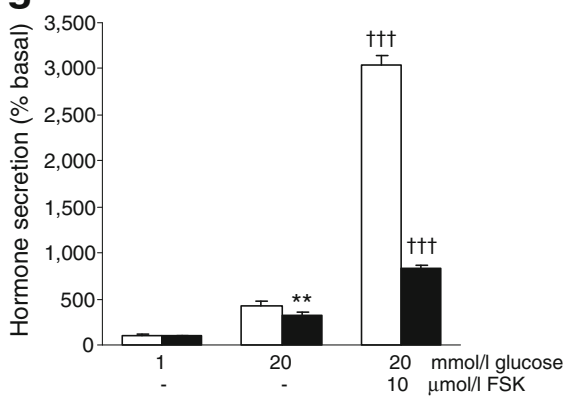

b

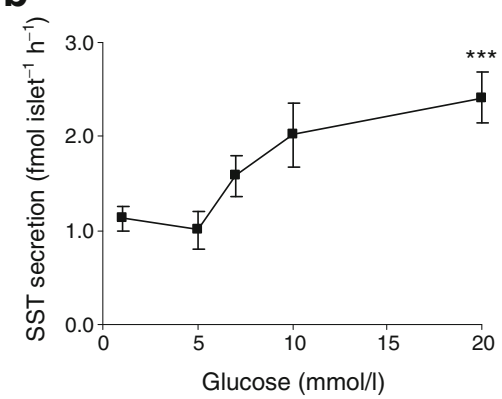

d
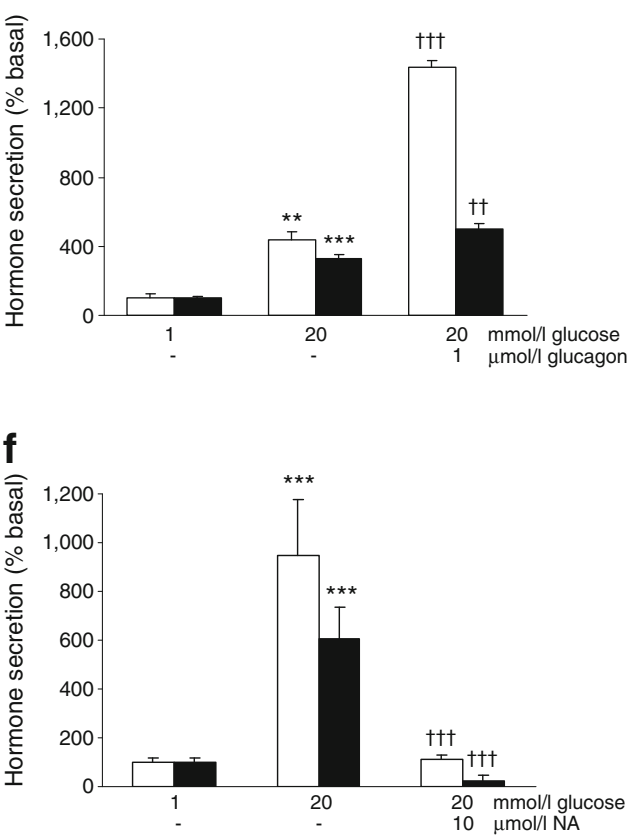

h

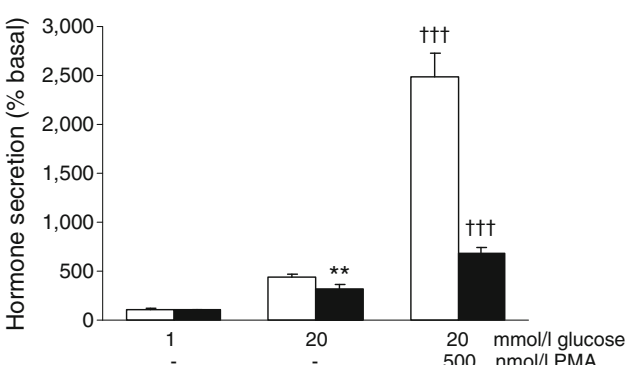

glucagon detected in cell lysates ( $p>0.2$ vs $0 \mathrm{ng}$ glucagon/ $\mathrm{ml}$ standard in RIA). In contrast to primary islets (Fig. 1), glucose-induced somatostatin secretion from TGP52 cells was not modified by the presence of exendin-4, glucagon or noradrenaline $(101 \pm 15 \%, 111 \pm 10 \%, 114 \pm 8 \%$ vs secretion at $20 \mathrm{mmol} / 1$ glucose, respectively; all $p>0.2)$, consistent with the detection of Glp1r, Gcgr and $\alpha 2$ aar (also known as Adra 2a) mRNA in mouse islets, but not in TGP52 cells (Fig. 3b). In contrast, the PI3-K inhibitor, LY294002, enhanced somatostatin release by $67 \pm 22 \%$ compared with secretion at $20 \mathrm{mmol} / 1$ glucose $(p=0.07)$.

Divergent parasympathetic modulation of insulin and somatostatin release While a range of common insulin secretagogues also stimulated somatostatin release from islets (Fig. 1), the acetylcholine analogue, carbachol, had opposite effects on islet beta and delta cells, enhancing glucose-induced insulin release, but inhibiting glucose- 
a
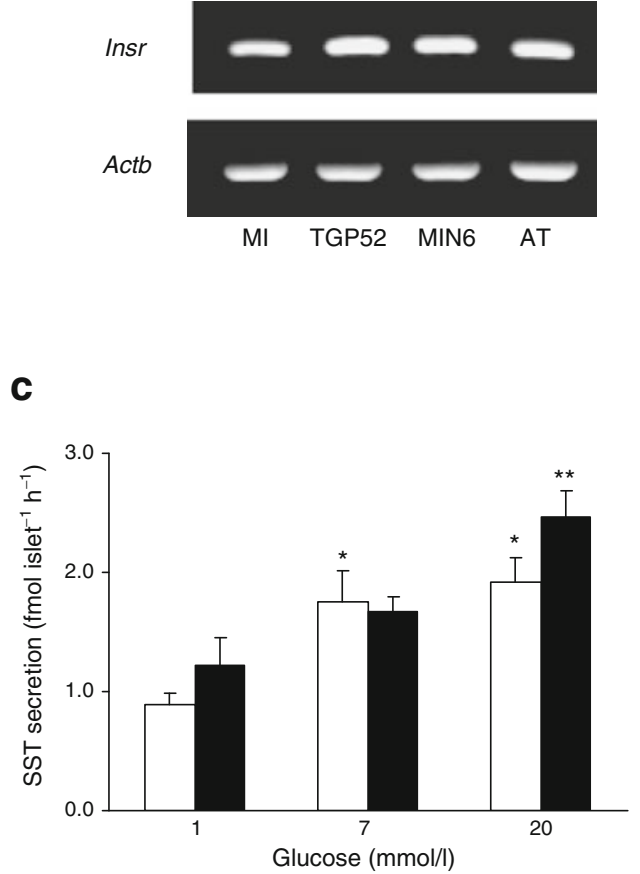

Fig. 2 Effect of insulin, IR-AB and the insulin receptor tyrosine kinase inhibitor, $\operatorname{HNMPA}(\mathrm{AM})_{3}$, on somatostatin secretion. a Expression of Insr (IR) and corresponding Actb ( $\beta$-actin) mRNA in mouse islets (MI), somatostatin-secreting TGP52 cells, MIN6 cells and adipose tissue (AT, positive control). b Somatostatin (SST) release from mouse islets incubated with low $(1 \mathrm{mmol} / \mathrm{l})$, intermediate $(7 \mathrm{mmol} / \mathrm{l})$ and high $(20 \mathrm{mmol} / \mathrm{l})$ glucose concentrations in the presence of $100 \mathrm{nmol} / \mathrm{l} \mathrm{ex}$ ogenous insulin (black bars; white bars, control). c As above (b), but

induced somatostatin secretion (Fig. 4a, b). The analogue also reduced glucose-induced somatostatin release from TGP52 cells, with $12 \%$ and $33 \%$ reductions, respectively, in two separate experiments. This differential effect on insulin and somatostatin secretion may be related to differences in receptor expression between the two pancreatic cell types. Thus, muscarinic receptor 3 (M3) has been linked to the stimulatory effect of parasympathetic activation on insulin secretion [33], and here RT-PCR analysis confirmed that M3 (also known as Chrm3) mRNA was expressed by mouse islets and MIN6 beta cells, but not by TGP52 cells (Fig. 4c). In contrast, muscarinic receptor 2 (M2) mRNA was highly expressed in TGP52 cells, present at low levels in primary islets and non-detectable in MIN6 cells (Fig. 4c), while muscarinic receptor 4 (M4) mRNA was expressed in all three cell types (Fig. 4c). M2 and M4 couple via pertussis toxin (PTX)-sensitive $\mathrm{G}_{\mathrm{i} / \mathrm{o}}$-proteins to inhibit adenylyl cyclase; here, $20 \mathrm{~h}$ pre-treatment with $100 \mathrm{ng} / \mathrm{ml} \mathrm{PTX}$ abolished the inhibitory effect of carbachol on somatostatin release (Fig. 4d). PTX pre-treatment also reversed noradrenalineinduced inhibition of somatostatin and insulin secretion, confirming the effective blockage of $\mathrm{G}_{\mathrm{i} / \mathrm{o}}$-coupled signalling by
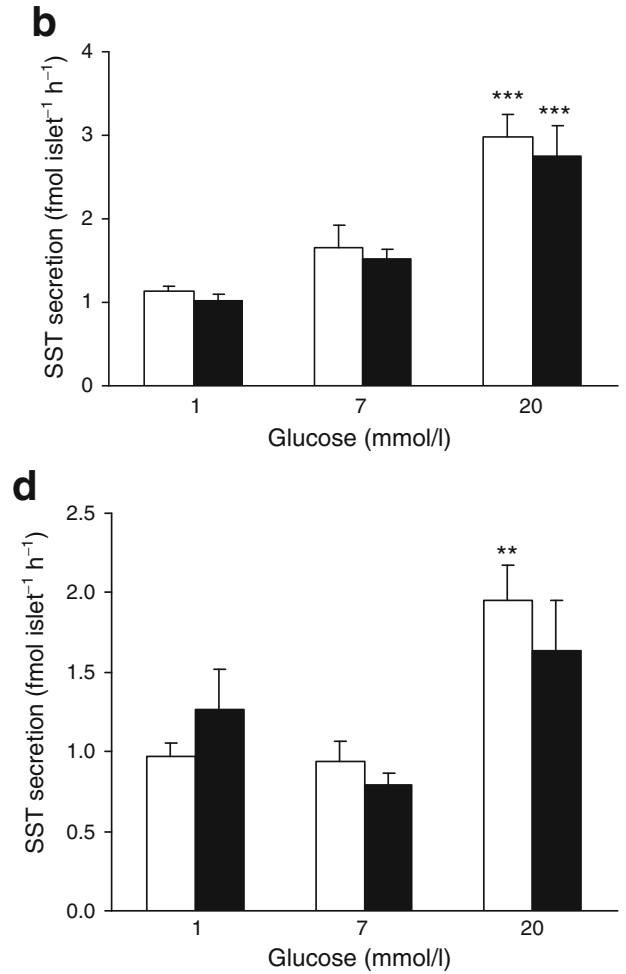

without exogenous insulin and following $48 \mathrm{~h}$ pre-incubation with $1 \mu \mathrm{g} / \mathrm{ml}$ IR-AB (black bars) or (d) $1 \mathrm{~h}$ pre-incubation with the insulin receptor tyrosine kinase inhibitor, $\operatorname{HNMPA}(\mathrm{AM})_{3}(10 \mu \mathrm{mol} / \mathrm{l}$; black bars). IR-AB (c) and HNMPA(AM) $)_{3}$ (d) were also added to the incubation buffer during the $1 \mathrm{~h}$ stimulation period. Data are expressed as means \pm SEM; $n=6-9 ;{ }^{*} p<0.05,{ }^{* *} p<0.01$ and ${ }^{* * *} p<0.001$, respectively, vs $1 \mathrm{mmol} / \mathrm{l}$ glucose alone

PTX (somatostatin: control $54 \pm 2 \%$ [means \pm SEM] of $20 \mathrm{mmol} / 1$ glucose, $p<0.001$ vs $20 \mathrm{mmol} / 1$ glucose only; PTX-treated $109 \pm 2 \% 20 \mathrm{mmol} / 1$ glucose, $p>0.2$; insulin: control $8.5 \pm 1 \%$ of $20 \mathrm{mmol} / 1$ glucose, $p<0.001$ vs $20 \mathrm{mmol} / \mathrm{l}$ glucose only; PTX-treated $62 \pm 6 \% 20 \mathrm{mmol} / \mathrm{l} \mathrm{glu}-$ cose, $p<0.05)$. Basal $(p<0.01)$ and glucose-induced somatostatin secretion $(p<0.001)$ was significantly enhanced following PTX-treatment in accordance with previous reports on insulin secretion [34]. Consistent with an involvement of $\mathrm{G}_{\mathrm{i} / \mathrm{o}}$-coupled receptors, the M2 antagonist, MTT, specifically reversed the inhibitory effect of carbachol on glucose-induced somatostatin release, without affecting carbachol-induced insulin secretion (Fig. 4e, f).

\section{Discussion}

Paracrine interactions between islet cells are important for normal hormone secretory responses $[6-9,11,22,23,25$, $35,36]$ and are likely to be involved in maintaining the tightly synchronised patterns of pulsatile insulin, somatostatin and glucagon release [37]. There is no doubt that delta 
Fig. 3 Secretory characteristics of the somatostatin-secreting TGP52 cell line. a Somatostatin (SST) secretory responses of TGP52 cells to insulin secretagogues. Values are expressed as percentage of basal somatostatin secretion at $1 \mathrm{mmol} / \mathrm{l} \mathrm{glu}-$ cose; $n=3-6$. b Expression of Glp1r mRNA (encoding the GLP-1 receptor), Gcgr mRNA (encoding the glucagon receptor) and $\alpha 2$ aar mRNA (encoding the $\alpha 2 \mathrm{a}$ adrenergic receptor) in mouse islets (MI) and the TGP52 cell line

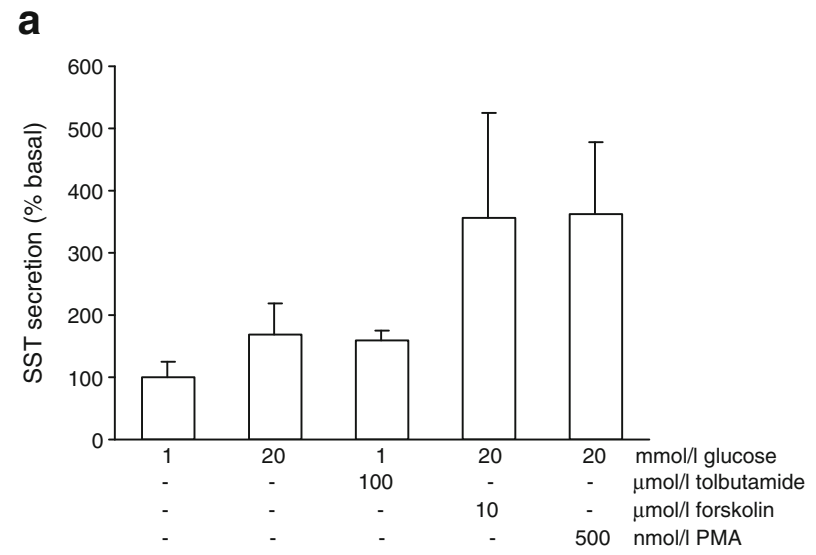

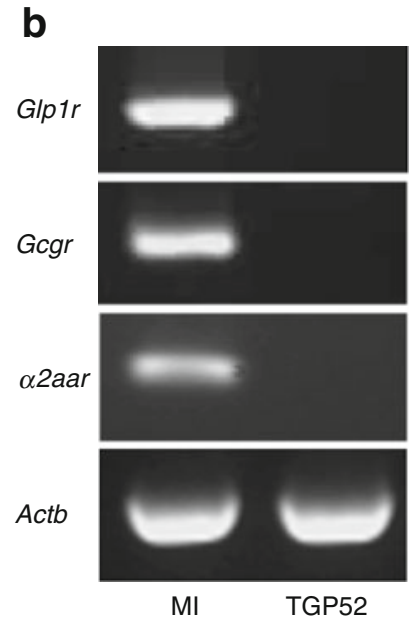

cell somatostatin exerts paracrine regulatory effects on islet beta cells [11, 25, 35], while circumstantial evidence exists that beta cells may exert a reciprocal regulation of delta cell function. Thus our previous report of INSR expression in single primary delta cells [21] was confirmed by our current studies using the TGP52 cell line; moreover, the similar
Fig. 4 Divergent effects of parasympathetic activation on insulin and somatostatin release correspond with differences in muscarinic receptor expression. a Glucose-induced insulin and (b) somatostatin (SST) release from mouse islets in the presence of carbachol (CCh), an acetylcholine analogue. c $M 3$ (also known as Chrm3), M2 (also known as Chrm2) and M4 (also known as Chrm4) mRNA expression in mouse islets (MI) and cell lines as indicated. d The inhibitory effect of carbachol on glucose-induced somatostatin release was abolished following $20 \mathrm{~h}$ treatment with $100 \mathrm{ng} / \mathrm{ml}$ PTX (black bars) (white bars, control) or (e) incubation in the presence of $10 \mu \mathrm{mol} / \mathrm{l} \mathrm{MTT}$, a M2 antagonist. f MTT had no effect on carbachol-induced insulin secretion. Data

$(\mathbf{a}, \mathbf{b}, \mathbf{d}-\mathbf{f})$ are expressed as means \pm SEM; $n=8$;

$* * * p<0.001$ vs $1 \mathrm{mmol} / 1$ glucose alone; ${ }^{\dagger \dagger} p<0.01$ and ${ }^{\dagger \dagger} p<0.001$, respectively, vs $20 \mathrm{mmol} / \mathrm{l}$ glucose alone; 林 $p<0.001$ vs $20 \mathrm{mmol} / \mathrm{l}$ glucose $+100 \mu \mathrm{mol} / 1$ carbachol
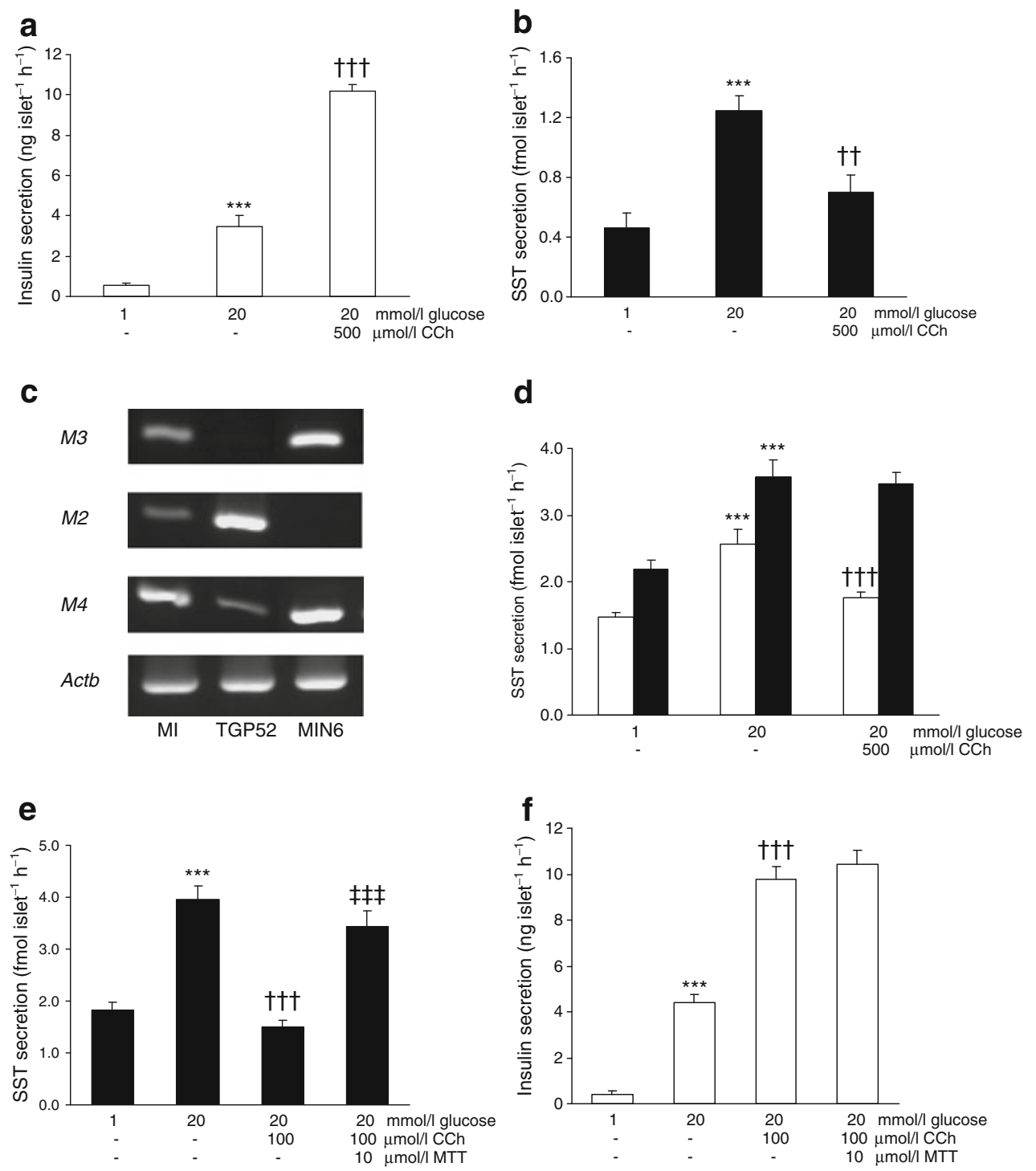
insulin and somatostatin secretory responses to a range of physiological and pharmacological stimuli are consistent with the notion that insulin acts in a paracrine way to regulate somatostatin secretion from delta cells. Glucose is the most important physiological regulator of islet hormone secretion and our data suggest a similar concentrationdependence of beta and delta cells in response to this stimulus. Under these conditions, it is possible that insulin plays a role as paracrine regulator of somatostatin release, since, at least in our hands, the two hormones were released at similar glucose concentrations. This is consistent with a previous study using human islets [10], but contrasts with other reports of enhanced delta cell sensitivity to glucose compared with beta cells, where glucose concentrations as low as 2 to $3 \mathrm{mmol} / \mathrm{l}$ initiated significant increases in somatostatin secretion from mouse islets [12, 38, 39]. Because of these reports, we routinely used a very low concentration of glucose $(1 \mathrm{mmol} / \mathrm{l})$ to assess basal, unstimulated levels of somatostatin secretion, but were consistently unable to detect any significant increases in somatostatin secretion from mouse islets at $5 \mathrm{mmol} / \mathrm{l}$ glucose, whereas we did observe (non-significant) increases in insulin and somatostatin release at 7 and $10 \mathrm{mmol} / 1$ glucose. This suggests that, in our studies, mouse beta and delta cells had similar thresholds for activation by glucose.

Despite comparable secretory responses of beta and delta cells to glucose and some other stimuli, our experiments manipulating insulin receptor activation suggest that somatostatin release is not modulated by insulin and that the regulatory effect of insulin secretagogues on the delta cell is therefore unlikely to be secondary to insulin release from beta cells. Thus, exogenous insulin had no effect on somatostatin release from mouse islets at concentrations of glucose that are either sub-stimulatory or stimulatory for the release of endogenous insulin. These observations are consistent with previous studies, in which exogenous insulin or immunoneutralisation had no marked effects on somatostatin release from isolated rat islets [22] or the perfused canine pancreas [23, 24], although insulin immunoneutralisation has been reported to inhibit somatostatin release from perfused human pancreas [25]. These differences may reflect species-dependent differences in islet architecture [40] or the different experimental models employed. A lack of detectable responses to exogenous insulin could also be caused by endogenous insulin occupying the insulin receptor. Thus, even under non-stimulatory conditions for mouse beta cells, the basal rates of insulin release measured in our experiments produced extracellular concentrations of 1 to $2 \mathrm{nmol} / \mathrm{l}$ in the incubation medium, more than sufficient to ensure occupation of the insulin receptor, whose $\mathrm{IC}_{50}$ is about 20 to $30 \mathrm{pmol} / \mathrm{l}$ [41]. However, the lack of effect of endogenous insulin on somatostatin secretion was consistent with the lack of effect on glucose-induced somatostatin release of two pharmacological strategies to block intraislet insulin signalling. Thus, basal and glucose-induced somatostatin release remained unaltered by pre-incubation with a blocking antibody against the insulin-binding region of the receptor or by the presence of the insulin receptor tyrosine-kinase inhibitor, HNMPA(AM) $)_{3}$, suggesting that a paracrine effect of insulin on delta cells is not required for glucose-induced somatostatin secretion. Activation of the insulin receptor leads to downstream activation of PI3-Kmediated signalling pathways, but the PI3-K inhibitor, LY294002, did not reduce glucose-induced somatostatin release, again suggesting that somatostatin secretion is not dependent on insulin receptor activation. The observed stimulatory effect of LY294002 on insulin and somatostatin secretion is in accordance with our previous report of enhancing, and possibly non-specific effects of the agent on insulin secretion [42], and corresponds to the similar stimulatory effect on somatostatin release from TGP52 cells that was observed in the present study.

Our experiments using mouse islets cannot rule out the possibility that beta cell secretory products other than insulin might influence somatostatin secretion from delta cells. To eliminate interactions from non-delta cells, we therefore assessed the secretory characteristics of the somatostatinsecreting TGP52 cell line. As with other islet hormonesecreting cell lines [43], the TGP52 cells contained very low levels of somatostatin compared with primary islets and exhibited variable secretory responsiveness, consistent with their transformed nature. Consequently, information on the regulation of somatostatin secretion obtained using TGP52 cells should be viewed as supplementary to that obtained from primary islet tissue, rather than definitive. The TGP52 cells did, however, show qualitatively similar secretory responses to glucose and the sulfonylurea, tolbutamide, suggesting that responsiveness to these initiators of secretion is intrinsic to delta cells, rather than being mediated indirectly. Glucose is accordingly reported to induce metabolic changes and electrical activity in beta and delta cells [44, 45], and both cell types have sulfonylureasensitive $\mathrm{K}_{\mathrm{ATP}}$-channels and depend on $\mathrm{Ca}^{2+}$ for exocytotic release of stored hormones [44-48]. The relative importance of $\mathrm{K}_{\mathrm{ATP}}$ channel closure for glucose-induced membrane depolarisation and concomitant somatostatin secretion from the delta cell was re-examined recently by Zhang et al [49], whose results suggest that somatostatin release is dependent on $\mathrm{K}_{\mathrm{ATP}}$-dependent and -independent processes, with the latter, at least in mouse islets, relying on $\mathrm{Ca}^{2+}$-induced $\mathrm{Ca}^{2+}$ release. Arginine also depolarises the plasma membrane, so the similarity in arginine-induced secretion from beta and delta cells in primary islets may indicate a general importance of membrane depolarisation in the stimulus-response pathway. Similarly, the stimulation of both insulin and somatostatin release from mouse islets by PMA and forskolin suggests 
an important role for protein kinase $\mathrm{C}$ and cAMP signalling in regulating hormone release, an interpretation supported by our finding that those pharmacological agents also stimulated somatostatin release from TGP52 cells. Finally, the similarity of response to the PI3-K inhibitor, LY294002, may indicate the involvement of similar, PI3-K-mediated signalling pathways in secretion from the two islet cell types.

The responses of beta and delta cells to receptor-mediated agonists will depend on receptor expression by the two cell types. However, despite initial reports that GLP-1 receptor (GLP-1R) was produced in the majority of beta, alpha and delta cells $[20,50]$, the same group was later unable to detect the receptor in alpha or delta cells using a range of different, highly sensitive immunohistochemical techniques [51], observations that supported earlier negative studies [52]. The absence of GLP-1R production by delta cells is at odds with the numerous reports that exendin-4 or GLP-1 exerted stimulatory effects on somatostatin release [15-20] and may suggest that GLP-1 modifies somatostatin secretion via an indirect mechanism [51]. In the present study, we were unable to detect GLP-1R in TGP52 cells. Moreover, in contrast to primary islets, TGP52 cells did not respond to the GLP-1 analogue, exendin-4, by exhibiting enhanced somatostatin release. These data suggest that GLP-1-induced somatostatin secretion could be dependent on factor(s) other than insulin from non-delta cells, although the lack of GLP-1R in TGP52 might also reflect the limitations of the cell line in representing primary tissue.

Glucagon stimulates somatostatin secretion in a number of experimental models, including isolated rodent islets [22], perfused canine [23] or human pancreas [25], and in rats in vivo [36]. The glucagon receptor has been detected in a subpopulation of primary delta cells by immunohistochemical analysis ( $11 \%$ vs $97 \%$ in beta cells [53]), although it is unclear whether this relatively low abundance is sufficient to account for the enhancing effect of glucagon on somatostatin secretion. In the present study, we were unable to detect the glucagon receptor in TGP52 cells and did not observe a glucagon-induced secretory response from these cells.

Adrenaline (epinephrine) has been shown to inhibit glucose-induced changes in $\left[\mathrm{Ca}^{2+}\right]_{\mathrm{i}}$ from primary delta cells [46] and pharmacological studies suggest that the observed inhibition of islet somatostatin release by noradrenaline is mediated via $\alpha$-adrenergic receptors $[54,55]$. This is supported by our findings that PTX treatment reversed noradrenaline-induced inhibition of somatostatin secretion. To our knowledge, however, there are no specific reports on $\alpha$-adrenergic receptor content in primary delta cells; we, moreover, were unable to detect $\alpha 2 \mathrm{a}$ adrenergic receptors on TGP52 cells. Our data suggest that the lack of receptor expression and lack of effect of noradrenaline on somatostatin release from TGP52 cells could reflect a role for non- delta cells in mediating the sympathetic inhibition of somatostatin release. Alternatively, the unresponsiveness of TGP52 cells may be a direct consequence of the specific absence of $\alpha$-adrenergic receptors in this cell line.

The divergent secretory responses to parasympathetic activation observed in this study support the notion that insulin released in response to carbachol does not modulate somatostatin secretion by a paracrine action. The corresponding differences in muscarinic receptor mRNA expression in islets, and in TGP52 and MIN6 cells also suggest that parasympathetic modulation of secretion is dependent on the presence of specific receptors in the different cell types. The importance of M3 for insulin secretion is well-established and has been reviewed [33]; our results confirmed its presence in islets and MIN6 cells, but not in TGP52 cells. In contrast, $M 2$ (also known as Chrm2) mRNA was highly expressed in TGP52 cells, and to a lesser extent in islets, perhaps reflecting expression of $M 2 \mathrm{mRNA}$ in the islet delta cell population only. M2 and M4 are mainly linked to PTX-sensitive $G_{i}$ or $G_{o}$ proteins, which mediate inhibition of processes such as cAMP production and activation of voltage-dependent $\mathrm{Ca}^{2+}$ channels [33]. These receptors have not been ascribed a physiological role in insulin secretion because of the limited effects of acetylcholine on cAMP production in islets [56], and also because the signalling pathways activated by acetylcholine in beta cells are insensitive to PTX [57]. However, our data suggest that M2 (and possibly also M4) plays an important role in mediating the effect of parasympathetic activation in the delta cell, since inactivation of $\mathrm{G}_{\mathrm{i} / \mathrm{o}}$-coupled receptors by PTX and specific antagonism of M2 by methoctramine reversed the carbachol-induced inhibition of somatostatin secretion.

In summary, we have shown that although a range of islet hormone secretagogues have similar effects on the release of insulin and somatostatin, this is not caused by an indirect, paracrine action of insulin on the delta cells. Instead, the parallel responses are likely to be caused by similarities in the stimulus-response pathways in beta and delta cells, and by similarities in the presence and abundance of specific receptors. Accordingly, our data demonstrate that the observed difference in response to parasympathetic activation is a direct consequence of variation in muscarinic receptor levels. Since the insulin receptor is produced in delta cells, we suggest that insulin may have other, non-secretory roles in delta cell function, as previously reported in the beta cell, where insulin is involved in regulation of apoptosis [32].

Funding A. Hauge-Evans is a RD Lawrence Fellow (Diabetes UK, BDA: 10/0003980). The authors are grateful for an equipment grant from Diabetes UK (BDA: RD07/0003510) for a gamma counter.

Duality of interest The authors declare that there is no duality of interest associated with this manuscript. 
Contribution statement In accordance with ICMJE requirements, all authors were involved in study conception and design, or analysis and interpretation of data, as well as in the drafting or revision of the manuscript. All authors approved the final version.

\section{References}

1. Bosco D, Orci L, Meda P (1989) Homologous but not heterologous contact increases the insulin secretion of individual pancreatic B cells. Exp Cell Res 184:72-80

2. Halban PA, Wollheim CB, Blondel B, Meda P, Niesor EN, Mintz DH (1982) The possible importance of contact between pancreatic islet cells for the control of insulin release. Endocrinology 111:8694

3. Hauge-Evans AC, Squires PE, Persaud SJ, Jones PM (1999) Pancreatic beta-cell-to-beta-cell interactions are required for integrated responses to nutrient stimuli: enhanced $\mathrm{Ca} 2+$ and insulin secretory responses of MIN6 pseudoislets. Diabetes 48:1402-1408

4. Hopcroft DW, Mason DR, Scott RS (1985) Insulin secretion from perifused rat pancreatic pseudoislets. In Vitro Cell Dev Biol 21:421-427

5. Luther MJ, Hauge-Evans A, Souza KL et al (2006) MIN6 betacell-beta-cell interactions influence insulin secretory responses to nutrients and non-nutrients. Biochem Biophys Res Commun 343:99-104

6. Brereton H, Carvell MJ, Persaud SJ, Jones PM (2007) Islet alphacells do not influence insulin secretion from beta-cells through cell-cell contact. Endocrine 31:61-65

7. Franklin I, Gromada J, Gjinovci A, Theander S, Wollheim CB (2005) Beta-cell secretory products activate alpha-cell ATPdependent potassium channels to inhibit glucagon release. Diabetes $54: 1808-1815$

8. Ishihara H, Maechler P, Gjinovci A, Herrera PL, Wollheim CB (2003) Islet beta-cell secretion determines glucagon release from neighbouring alpha-cells. Nat Cell Biol 5:330-335

9. Ravier MA, Rutter GA (2005) Glucose or insulin, but not zinc ions, inhibit glucagon secretion from mouse pancreatic alpha-cells. Diabetes 54:1789-1797

10. Walker JN, Ramracheya R, Zhang Q, Johnson PR, Braun M, Rorsman P (2011) Regulation of glucagon secretion by glucose: paracrine, intrinsic or both? Diabetes Obes Metab 13(Suppl 1):95105

11. Hauge-Evans AC, King AJ, Carmignac D et al (2009) Somatostatin secreted by islet delta-cells fulfills multiple roles as a paracrine regulator of islet function. Diabetes 58:403-411

12. Vieira E, Salehi A, Gylfe E (2007) Glucose inhibits glucagon secretion by a direct effect on mouse pancreatic alpha cells. Diabetologia 50:370-379

13. Cejvan K, Coy DH, Holst JJ, Cerasi E, Efendic S (2002) Gliclazide directly inhibits arginine-induced glucagon release. Diabetes 51 (Suppl 3):S381-S384

14. Sako Y, Wasada T, Umeda F, Ibayashi H (1986) Effect of glibenclamide on pancreatic hormone release from isolated perifused islets of normal and cysteamine-treated rats. Metabolism 35:944 949

15. Guenifi A, Ahren B, Abdel-Halim SM (2001) Differential effects of glucagon-like peptide-1 (7-36)amide versus cholecystokinin on arginine-induced islet hormone release in vivo and in vitro. Pancreas 22:58-64

16. Silvestre RA, Rodriguez-Gallardo J, Egido EM, Marco J (2003) Interrelationship among insulin, glucagon and somatostatin secretory responses to exendin- 4 in the perfused rat pancreas. Eur J Pharmacol 469:195-200
17. D'Alessio DA, Fujimoto WY, Ensinck JW (1989) Effects of glucagon-like peptide I-(7-36) on release of insulin, glucagon, and somatostatin by rat pancreatic islet cell monolayer cultures. Diabetes 38:1534-1538

18. Fehmann HC, Hering BJ, Wolf MJ et al (1995) The effects of glucagon-like peptide-I (GLP-I) on hormone secretion from isolated human pancreatic islets. Pancreas 11:196-200

19. Gros L, Thorens B, Bataille D, Kervran A (1993) Glucagon-like peptide-1-(7-36) amide, oxyntomodulin, and glucagon interact with a common receptor in a somatostatin-secreting cell line. Endocrinology 133:631-638

20. Heller RS, Aponte GW (1995) Intra-islet regulation of hormone secretion by glucagon-like peptide-1-(7-36) amide. Am J Physiol 269:G852-G860

21. Muller D, Huang GC, Amiel S, Jones PM, Persaud SJ (2007) Gene expression heterogeneity in human islet endocrine cells in vitro: the insulin signalling cascade. Diabetologia 50:1239-1242

22. Murakami K, Taniguchi H, Tamagawa M, Ejiri K, Baba S (1982) Modulation of somatostatin release by endogenous glucagon and insulin: physiological relationship between A, $\mathrm{B}$ and D cells in rat pancreatic islets. Endocrinol Jpn 29:503508

23. Patton GS, Ipp E, Dobbs RE, Orci L, Vale W, Unger RH (1977) Pancreatic immunoreactive somatostatin release. Proc Natl Acad Sci USA 74:2140-2143

24. Stagner J, Samols E, Polonsky K, Pugh W (1986) Lack of direct inhibition of insulin secretion by exogenous insulin in the canine pancreas. J Clin Invest 78:1193-1198

25. Brunicardi FC, Kleinman R, Moldovan S et al (2001) Immunoneutralization of somatostatin, insulin, and glucagon causes alterations in islet cell secretion in the isolated perfused human pancreas. Pancreas 23:302-308

26. Trimble ER, Gerber PP, Renold AE (1981) Abnormalities of pancreatic somatostatin secretion corrected by in vivo insulin treatment of streptozotocin-diabetic rats. Diabetes 30:865-867

27. Gey GO, Gey MK (2008) Maintenance of human normal cells in continuous culture, preliminary report: cultivation of mesoblastic tumours and normal cells and notes on methods of cultivation. Am J Cancer 27:45-76

28. Bradford MM (1976) A rapid and sensitive method for the quantitation of microgram quantities of protein utilizing the principle of protein-dye binding. Anal Biochem 72:248-254

29. Hauge-Evans AC, Squires PE, Belin VD et al (2002) Role of adenine nucleotides in insulin secretion from MIN6 pseudoislets. Mol Cell Endocrinol 191:167-176

30. Gromada J, Holst JJ, Rorsman P (1998) Cellular regulation of islet hormone secretion by the incretin hormone glucagon-like peptide 1. Pflugers Arch 435:583-594

31. Lobner K, Steinbrenner H, Roberts GA et al (2002) Different regulated expression of the tyrosine phosphatase-like proteins IA-2 and phogrin by glucose and insulin in pancreatic islets: relationship to development of insulin secretory responses in early life. Diabetes 51:2982-2988

32. Muller D, Jones PM, Persaud SJ (2006) Autocrine anti-apoptotic and proliferative effects of insulin in pancreatic beta-cells. FEBS Lett 580:6977-6980

33. Gilon P, Henquin JC (2001) Mechanisms and physiological significance of the cholinergic control of pancreatic beta-cell function. Endocr Rev 22:565-604

34. Persaud SJ, Jones PM, Howell SL (1989) Effects of Bordetella pertussis toxin on catecholamine inhibition of insulin release from intact and electrically permeabilized rat islets. Biochem J 258:669675

35. Cejvan K, Coy DH, Efendic S (2003) Intra-islet somatostatin regulates glucagon release via type 2 somatostatin receptors in rats. Diabetes 52:1176-1181 
36. Utsumi M, Makimura H, Ishihara K, Morita S, Baba S (1979) Determination of immunoreactive somatostatin in rat plasma and responses to arginine, glucose and glucagon infusion. Diabetologia $17: 319-323$

37. Hellman B (2009) Pulsatility of insulin release - a clinically important phenomenon. Ups J Med Sci 114:193-205

38. Hoy M, Olsen HL, Bokvist K, Petersen JS, Gromada J (2003) The imidazoline NNC77-0020 affects glucose-dependent insulin, glucagon and somatostatin secretion in mouse pancreatic islets. Naunyn Schmiedebergs Arch Pharmacol 368:284-293

39. Obermuller S, Calegari F, King A et al (2010) Defective secretion of islet hormones in chromogranin-B deficient mice. PLoS One 5: e8936

40. Cabrera O, Berman DM, Kenyon NS, Ricordi C, Berggren PO, Caicedo A (2006) The unique cytoarchitecture of human pancreatic islets has implications for islet cell function. Proc Natl Acad Sci USA 103:2334-2339

41. Schaffer L, Brand CL, Hansen BF et al (2008) A novel highaffinity peptide antagonist to the insulin receptor. Biochem Biophys Res Commun 376:380-383

42. Persaud SJ, Asare-Anane H, Jones PM (2002) Insulin receptor activation inhibits insulin secretion from human islets of Langerhans. FEBS Lett 510:225-228

43. Persaud SJ (1999) Pancreatic beta-cell lines: their roles in beta-cell research and diabetes therapy. Adv Mol Cell Biol 29:21-46

44. Gopel SO, Kanno T, Barg S, Rorsman P (2000) Patch-clamp characterisation of somatostatin-secreting-cells in intact mouse pancreatic islets. J Physiol 528:497-507

45. Quesada I, Todorova MG, Soria B (2006) Different metabolic responses in alpha-, beta-, and delta-cells of the islet of Langerhans monitored by redox confocal microscopy. Biophys J 90:26412650

46. Berts A, Ball A, Dryselius G, Gylfe E, Hellman B (1996) Glucose stimulation of somatostatin-producing islet cells involves oscillatory Ca2+ signaling. Endocrinology 137:693697
47. Hermansen K, Christensen SE, Orskov H (1979) Characterization of somatostatin release from the pancreas: the role of potassium. Scand J Clin Lab Invest 39:717-722

48. Hermansen K, Christensen SE, Orskov H (1979) Characterisation of somatostatin release from the pancreas: the role of calcium and acetylcholine. Diabetologia 16:261-266

49. Zhang Q, Bengtsson M, Partridge C et al (2007) R-type Ca(2+)channel-evoked CICR regulates glucose-induced somatostatin secretion. Nat Cell Biol 9:453-460

50. Heller RS, Kieffer TJ, Habener JF (1997) Insulinotropic glucagonlike peptide I receptor expression in glucagon-producing alphacells of the rat endocrine pancreas. Diabetes 46:785-791

51. Tornehave D, Kristensen P, Romer J, Knudsen LB, Heller RS (2008) Expression of the GLP-1 receptor in mouse, rat, and human pancreas. J Histochem Cytochem 56:841-851

52. Moens K, Heimberg H, Flamez D et al (1996) Expression and functional activity of glucagon, glucagon-like peptide I, and glucose-dependent insulinotropic peptide receptors in rat pancreatic islet cells. Diabetes 45:257-261

53. Kieffer TJ, Heller RS, Unson CG, Weir GC, Habener JF (1996) Distribution of glucagon receptors on hormone-specific endocrine cells of rat pancreatic islets. Endocrinology 137:5119-5125

54. Itoh M, Gerich JE (1982) Adrenergic modulation of pancreatic somatostatin, insulin, and glucagon secretion: evidence for differential sensitivity of islet A, B, and D cells. Metabolism 31:715-720

55. Samols E, Weir GC (1979) Adrenergic modulation of pancreatic $\mathrm{A}, \mathrm{B}$, and D cells alpha-adrenergic suppression and betaadrenergic stimulation of somatostatin secretion, alpha-adrenergic stimulation of glucagon secretion in the perfused dog pancreas. J Clin Invest 63:230-238

56. Gagerman E, Idahl LA, Meissner HP, Taljedal IB (1978) Insulin release, cGMP, cAMP, and membrane potential in acetylcholinestimulated islets. Am J Physiol 235:E493-E500

57. Dunlop ME, Larkins RG (1986) Muscarinic-agonist and guanine nucleotide activation of polyphosphoinositide phosphodiesterase in isolated islet-cell membranes. Biochem J 240:731-737 